\title{
The State of Responsibility to Protect Inception in ASEAN Regionalism
}

\author{
Muhammad Rum ${ }^{1}$ \\ Department of International Relations, Universitas Gadjah Mada, Indonesia
}

Keywords

ASEAN; regionalism;

responsibility to protect

\begin{abstract}
As a regional organization, ASEAN upholds its core principles of noninterference, consultation and consensus. Meanwhile, Responsibility to Protect (R2P) encourages the need for the international community's intervention to a country that falls to its citizens. Hence, this creates tension between ASEAN principles and R2P. The tension is reflected when the limited capacity of a member state's government might invite humanitarian intervention from the international community. This research aims to discuss how Southeast Asian regionalism adapts to this situation and is undergoing dynamic reformulation to reconcile ASEAN Way and humanitarian principles. In contemporary Southeast Asian Studies, the extent of R2P inception in ASEAN regional cooperation is understudied. These methods utilize a reductionist approach in I.R. studies by explaining ASEAN through the analysis of individual actors based on a constructivism school of thought. The data taken from the interviews are utilized to confirm ASEAN and member states' positions. This study argues that the traditional constructivist tipping point measurement for an international norm needs to be revisited. The tipping points for R2P in international forums may not necessarily be well-reflected at the regional level.
\end{abstract}

\section{Introduction}

As a regional political bloc, ASEAN is infamous for its adherence to the principles of noninterference and its use of a consensus mechanism in decision-making. For supporters, these principles are identified as the prevailing nostrum for regional unification, given that ASEAN is now more than fifty years old. On the other hand, critics identify these principles as hindering ASEAN in overcoming essential problems such as transnational crimes, environmental degradation, and-most notablyhuman rights.

Elsewhere, the most advanced regional organisation, namely the European Union (EU), has institutionalised a norm that ensures all member states have a unified stance in

${ }^{1}$ Corresponding email \m.rum@ugm.ac.id 
protecting human rights. First, according to the Copenhagen criteria ${ }^{2}$, no European country may be enrolled in the $\mathrm{EU}$ if human rights violations still occur. Second, if there are serious human rights violations within or without the EU, all member countries have the responsibility to stop them. Common security and foreign policy in the EU has enabled member states to adhere to a newly formulated norm on humanitarian intervention, one widely known as the responsibility to protect (R2P).

However, during its formulation, understandings of R2P were quite dynamic; this has been revised and toned down over time. When it was first introduced in 2001, R2P emphasized military intervention in crimes against humanity, war crimes, ethnic cleansing, genocide, environmental problems, and natural disasters. It reached the milestone of enactment in the 2005 World Summit and became the subject of international debates. Meanwhile, since the formulation of the UN Secretary General's report on the Implementation of Responsibility to Protect in 2009, the international community has witnessed a shift in the R2P norm, focusing more on "prevention" than "direct intervention" (Alexandra, 2012).

In the European case, the most striking implementation of R2P is the EU's intervention in Libya in March 2011. Following the Arab Spring in Tunisia, intense protests demanding a regime change in Libya happened between February and

\footnotetext{
2 Copenhagen criteria is named after the Presidency Conclusions Copenhagen European Council meeting on 21-22 June 1993 to set the standard for EU new memberships. There are three criteria that a new member has to fulfill in order to join the EU, namely political criteria (stable democracy, rule of law, human rights and protection to minorities), economic criteria (capacity to cope with competitive economy and functioning market economy), and administrative criteria (ability to implement the enrollment process and to perform membership obligations). These criteria are then stated in (the Copenhagen Declaration of June 1993 as a legally binding EU document. Please refer to the text of the document, available online at

http://www.europarl.europa.eu/enlargement/ec/pdf/cop en.pdf.

3 As stated by the then NATO Secretary General, Anders Fogh Rasmussen, at press conference on 24 March 2011. Please refer to the transcribed release available online through NATO webpage, "NATO
}

August 2011. Muammar Gaddafi's regime announced that it would hunt down people who fought for regime change. Gaddafi's administration was believed to have committed crimes against humanity by killings civilians. Considering these developments, NATO allies, backed by UN security council resolution ${ }^{3}$, sanctioned the Gaddafi regime by implementing a no-fly zone and launching surgical airstrikes against military targets. NATO forces, with the aid of countries such as Sweden, Jordan, Qatar, and the United Arab Emirates, participated in these strikes. The French air force hit Libyan army vehicles and tanks, working in conjunction with the British air force to ensure air superiority. EU member states such as the Netherlands, Belgium, Denmark, Italy, Spain, and Sweden also enforced a no-fly zone over Libya. This intervention turned the tides of war in Libya and enabled rebels to depose Gaddafi in October 2011.

In the aftermath of the Libyan crisis, despite dissenting opinions from the Arab League $^{4}$ and British Lawmakers such as Emily Thornberry ${ }^{5}$, scholars like Pattison argued that regionalism such as that in the EU could help protect Libyan people from state atrocities and a failure to act against state atrocitiesis morally wrong (Pattison, 2011, p. 276). Through regionalism, institutionalising the $\mathrm{R} 2 \mathrm{P}$ norm is plausible. Reflecting on the contemporary issues in Southeast Asia, it is interesting to see how different actors within ASEAN have perceived

Secretary General's statement on Libya no-fly zone" https://www.nato.int/cps/en/natolive/news 71763.htm

${ }^{4}$ On March 2011, Arab League's secretary general, Amr Moussa expressed that the intention of Arab League in approving no-fly-zone over Libya was to prevent Moammar Gaddafi's air force in bombing Libyan civilians, and not to bless US and EU airstrikes. Hence, Arab League was reconsidering its support to the intervention. Please refer to the Wahington Post report published on 20 March 2011, available online at https://www.washingtonpost.com/world/arableague-condemns-broad-bombing-campaign-in-

libya/2011/03/20/AB1pSg1_story.html?noredirect=on.

${ }^{5}$ As reported by the New York Times in 14 September 2016, British Lawmakers, particularly from the opposition labor party, consider that David Cameron made a major mistake in intervening in Libya. Please refer to the report at https://www.nytimes.com/2016/09/15/world/europe/britain-libyaintervention.htm 
R2P. Several cases in the region need such assessment; take, for example, Cyclone Nargis in Myanmar in 2008 (and the government's inability to protect victims); the Rohingya crisis in Rakhine State, Myanmar, in 2017-2018; extra-judicial measures in the Philippines in 2016-2017, and the prolonged rule of the Thai military junta since 2014.

In 2008, former Secretary-General of ASEAN, Surin Pitsuwan stated that he supported R2P in the case of ASEAN involvement in settling tensions between the Myanmar junta and the international community over Cyclone Nargis. At the moment, the Rohingya people in Myanmar are not given citizenship. Despite having lived in Myanmar territory for centuries, Rohingya people in Myanmar have been deemed illegal immigrants. Since the early 1990s, the lack of protection of Rohingya civil liberty and human rights has forced about 400,000 Rohingyas to leave the country. Unfortunately, Myanmar's neighbour, Bangladesh, has been reluctant to welcome refugees. Indonesia, notably Minister of Foreign Affairs, Retno Marsudi, engaged Myanmar actively through 2017. Such application of direct pressure is considered unusual within the context of ASEAN.

Considering the traditional mechanisms in ASEAN-consultation, consensus, and noninterference the active diplomacy of Pitsuwan and Marsudi might help us understand the inception of R2P. However, the extent to which the R2P norm has influenced ASEAN regional cooperation in contemporary issues is understudied. As such, further examination is needed to assess the level of R2P incorporation in the region. This paper aims to answer this question through a Southeast Asian perspective by mapping the opinions and stances of (1) state leaders, (2) ASEAN bureaucrats, and (3) scholars in the region. As such, it aims to answer the question of how different actors in ASEAN have utilised regional cooperation to incorporate the R2P norm in ASEAN.

\section{Literature Review}

Under the 2005 World Summit Outcome Document on the Responsibility to Protect, should a sovereign state fail to protect its people from atrocities, various UN bodies and international community members (including regional organisations) should take necessary and appropriate measures (Bellamy \& Drummon, 2011, p. 183). This proposition could be the basis of ASEAN's adoption of the R2P norm. However, debate and dissenting opinions have emerged from different actors within the region. Apparently, member states have taken careful measures to avoid expressing frank positions. Unlike Surin Pitsuwan and the Indonesian government-represented by Minister of Foreign Affairs, Retno Marsudi never officially announced R2P as the basis of its policy towards Myanmar in 2017-2018.

Nonetheless, the actions of the Indonesian foreign ministry reflected its agerness to implement this principle, albeit in the form of restricted criticism. Other ASEAN leaders might as well have the same strategy, but not proposing R2P directly. This is possible due to the character of ASEAN regionalism, which emphasises harmony, consultation, and consensus. More vocal actors, such as Fidel Valdez Ramos of the Philippines, might openly promote the norm, but subtler leaders such as Susilo Bambang Yudhoyono might deliver their messages in riddles. This is an interesting development, and its examination can lead to striking findings.

The mapping of various actors' positions on R2P in ASEAN will be traced through existing reports and research. In the case of the Indonesian position, this can be determined based on discussions with Foreign Minister Retno Marsudi in December 2017. With regards to scholars' persepectives focusing on R2P in ASEAN, Yukiki Nishikawa proposes three categories of international relations: the sceptics, the 
incrementalists, and the accommodationists (Nishikawa, 2018).

There exists literature supporting each position. Sceptics are those who do not believe that R2P can be realised in Southeast Asia due to its cultural and political context (Capie, 2012). Capie argues that the region has not internalised the norm, and it can be proven through two points: first, the primary proponents of this norm are ASEAN outsiders; second, ASEAN member states only accept R2P agendas that benefit them and discard the rest (Capie, 2012). Incrementalists, meanwhile, believe that ASEAN member states may gradually adopt R2P, albeit more slowly than expected. It is also necessary to contextualise the R2P concept in Southeast Asian localities in order to be accepted. Kraft believes that R2P mainstreaming in Southeast Asia needs a methodological shift to succeed (Kraft, 2012). Meanwhile, accommodationists argue that ASEAN member states will most likely consider the importance of sovereignty cautiously, while at the same time reconciling the principles of human rights (Bellamy \& Drummon, 2011). Alexandra supports the idea that democratisation in Southeast Asia provides opportunities to apply R2P core principles in ASEAN (Alexandra, 2012).

Yukiko Nishikawa developed another approach that pinpoints the inherent limitation of R2P. In the case of the Rohingyas, their contested citizenships may result in the unintended consequence of being left unprotected by the governments (Nishikawa, 2018). However, Nishikawa argues that in recent times, Southeast Asian countries have developed a more caring society in protecting the people against states' atrocities. Hence, to conclude that ASEAN member states are refusing to protect their people is a premature generalisation (Nishikawa, 2018).

\footnotetext{
${ }^{6}$ Based on Mas'oed unit of analysis typology, ASEAN as a regional organization is considered as a group of states. Hence, the level of analysis is in the multilateral of regional stage of analysis.
}

\section{Reductionist Approach International Relations Studies}

In order to explain ASEAN's behaviour as a regional bloc, this study borrows Mohtar Mas'oed's levels of analysis. According to Mas'oed, every unit of analysis and explanation consists of five levels: individual level, group of individuals level, state level, group of states level, and international level (Mas'oed, 1990, pp. 40-42). Mas'oed suggests that an international scholar might use various combinations of units of analysis and explanation. Explaining ASEAN, in which the unit of analysis would be at the group of states level, does not necessarily need to involve regionalism. Instead, he proposes three different approaches: 1 . A correlationist explanation, requiring the same level at both analysis and explanation; 2. An inductionist explanation, requiring a higher level unit of explanation (for example, explaining an inquiry into state behaviour through the international situations and systems that force the state to behave as such); and 3. A reductionist explanation, requiring a lower unit of explanation (for instance, explaining state behaviour through the psychology or political calculations of its leader) (Mas'oed, 1990, p. 38). This can be seen on Graphic 6 below, utilizing the mapping methods offered above. This study uses a reductionist approach in explaining the behaviour of ASEAN (the group of states ${ }^{6}$ - level of analysis) through the exercise of persuasion by various political actors in Southeast Asia (individual unit - level of explanation). 


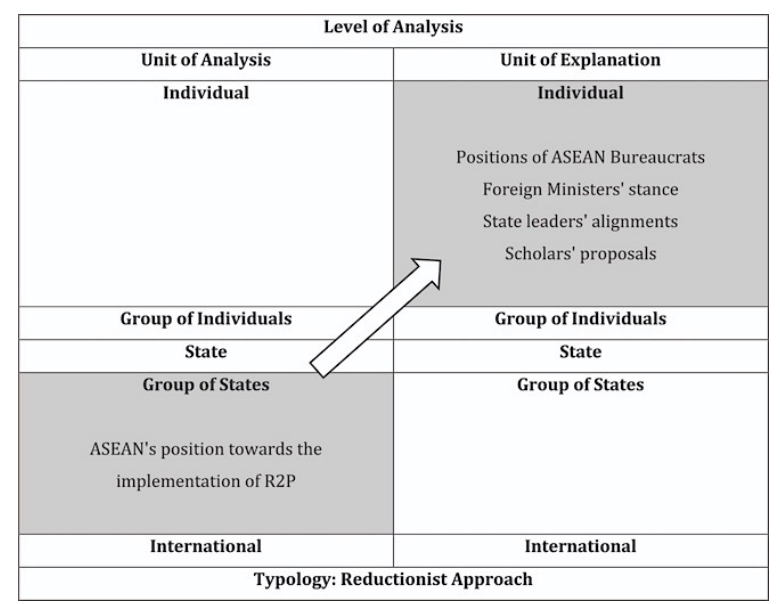

Figure 1. Correlation between Unit of Analysis and Unit of Explanation in the study of ASEAN and R2P (Source: Author's compilation)

How is a reductionist approach justifiable in this research? The key lies in the use of Finnemore and Sikkink's method of assessing whether a new international norm has been internalised. Finnemore and Sikkink argue that, in the internalisation process, the dominant actors advocating a norm are bureaucrats, lawyers, and professionals, who seek to achieve conformity (Finnemore \& Sikkink, 1998, p. 898).

The use of R2P and its correlation with regional cooperation in ASEAN is understudied. Discourse over this principle tends to be muted; as we witnessed at the 2016 ASEAN retreat, R2P is pragmatically used but officially unspoken. As such, studying various actors' positions will greatly benefit the prediction of ASEAN's future trajectories. This research will focus on Indonesia's position, as it remains one of the most important and influential of ASEAN's member states. By analysing the debate of R2P in ASEAN, this study will also contribute to future research into ASEAN regionalism and evolving international norms. Third, this study will enrich the literature on the Indonesian administration's

\footnotetext{
${ }^{7}$ This declaration is adopted by the Asian States delegations which attended the meeting at Bangkok on 29 March-2 April 1993 to prepare their position for the World Conference on Human rights as
}

foreign policy legacy, as we have seen shifts from time to time.

\section{Analysis of R2P Inception in ASEAN}

The R2P concept was preceded by the formulation of an idea called "sovereignty as responsibility", developed by Francis Deng and Roberta Cohen in the 1990s (Bellamy \& Drummon, 2011, p. 182). At the time, Deng was the UN Special Representative on Internally Displaced Persons, while Cohen was a senior fellow at the Brooking Institution. They argued that every sovereign state should be responsible for ensuring the well-being of the people. If a state cannot do so, then it should invite and welcome the assistance of the international community. States in trouble have two options. First, as mentioned before, they can work handin-hand with foreign countries and donors to solve their problem. Second, they can reject the involvement of external powers or obstruct efforts. The latter option would be regarded as sacrificing sovereign legitimacy. The first implementation of this concept was the involvement of NATO in Kosovo, in which UN Secretary-General Kofi Annan identified the concept of "sovereignty as responsibility" as the motive behind the intervention.

Over time, debates emerged over the contradiction between the rights and responsibilities of sovereignty. More countries believed that the protection of their selfdetermination was essential, even as they recognised fundamental human rights. The Final Declaration of the Regional Meeting for Asia of the World Conference on Human Rights in $1993^{7}$ shows that Asian countries, mainly, were willing to uphold human rights under the condition that cultural contexts be respected; for instance, governments sought to run their countries in a

mandated by the General Assembly resolution 46/116 of 17 December 1991. Please refer to the declaration text available online at https://www.ru.nl/publish/pages/688605/bangkok-eng.pdf. 
multiverse of cultures, as many Asian countries perceived their societies as families and the government as an authoritative "father". The implementation of sovereignty as responsibility, thus, was challenged by strict cultural interpretations of sovereignty.

An attempt to improve the concept was undertaken by Professor Gareth John Evans of the Australian National University, who was then the chair of the International Commission on Intervention and State Sovereignty (ICISS), established by the Canadian government. Evans' basic premise argues that violence and massacres of the innocent people cannot be universally ignored, while the state's sovereignty is not a license to kill (Evans, 2008, p. 11). ICISS came up with the concept of R2P and its technicalities, addressing guidelines for such questions as "When to intervene?", "What is the code of conduct?", and "How to use the Veto?" (Bellamy \& Drummon, 2011, p. 183). These guidelines were submitted to the 2005 World Summit, and it was agreed that the intervention applied to war crimes, crimes against humanity, ethnic cleansing, and genocide.

The main obstacle in the internalisation of R2P in ASEAN has been the principle of noninterference. Based on its historical development, ASEAN has traditionally been characterised by an emphasis on harmony over a conflictual or competitive approach. Former ASEAN SecretaryGeneral Rodolfo C. Severino argues that ASEAN member states' aspiration to uphold the noninterference principle is influenced by an

\footnotetext{
${ }^{8}$ Papua is located in the eastern part of Indonesian archipelago. Chauvel and Bhakti suggest that central government authority in Papua is challenged mainy by the Free Papua Organization.

9 The conflict in Mindanao has deep historical roots involving the struggle of the Moro people (refusing of being identified as Filipinos) for war of independence against the Spanish, the American, and the Philippines central government Invalid source specified.

$1076 \%$ of population Yala, Narathiwat and Pattani have inherited the Kingdom of Pattani's culture and Islamic faith. Prolonged conflicts in Southern Thailand is rooted on the historical and socio-cultural background of Muslim Malay insurgencies against the ruling Buddhist dominated Kingdom of Thailand.

${ }^{11}$ Article 23. Good Offices, Conciliation and Mediation
}

awareness that Southeast Asian countries are prone to domestic conflict. Most Southeast Asian countries are still struggling with their unfinished national building, rooted in their inheritance of fragmented societies (Severino, 2006). This unfinished nation-building has resulted in ethnonationalism and secession sentiments, spawning from Aceh and West Papua in Indonesia ${ }^{8}$, Mindanao in the Philippines, and Southern Thailand's provinces of Pattani, Yala and Narathiwat. ${ }^{10}$ This made Southeast Asian countries mistrust the intervention of foreign powers, a conservative belief that firmly gripped ASEAN for about 40 years.

Momentum for change came with the democratisation of Indonesia following 1998 and the occurrence of several major natural disasters. ASEAN's role in bridging the international community and Indonesia in responding to the Aceh earthquake and tsunami in 2004 offered a means for more open and frank interactions between member states and eventually became the momentum for a new international norm on disaster management (Rum, 2016). This ultimately created a plausible environment for the inducement of the ASEAN Charter.

To what extent has the ASEAN Charter helped create an environment for change? Under the Charter, the basic principles remain the same: non-interference, consultation, and consensus. This is reflected in Articles 23, 26, and 27, which allow ASEAN to offer mediation and relay unsolved disputes to the ASEAN Summit."1 The leaders of ASEAN states remain the supreme

1. Member States which are parties to a dispute may at any time agree to resort to good offices, conciliation or mediation in order to resolve the dispute within an agreed time limit.

2. Parties to the dispute may request the Chairman of ASEAN or the Secretary-General of ASEAN, acting in an ex-officio capacity, to provide good offices, conciliation or mediation.

Article 26. Unresolved Disputes

When a dispute remains unresolved, after the application of the preceding provisions of this Chapter, this dispute shall be referred to the ASEAN Summit, for its decision.

Article 27. Compliance 
overseeing body for monitoring compliance. As such, the veto of a member state's head of government would be enough to postpone or cancel an issue's being discussed in the summit.

Nevertheless, the ASEAN Charter does allow member states to express concern over dire situations in other countries through the concept of enhanced interaction, a result of a dynamic compromise between conservatives and reformists such as de facto Malaysian opposition leader, Anwar Ibrahim, and Surin Pitsuwan. According to Article 14, ASEAN has the mandate to ensure the development of the ASEAN Intergovernmental Commission on Human Rights (AICHR); however, its role is still limited, and ASEAN member countries rejected Indonesia's proposal to enable AICHR to dispatch human rights investigators and collect reports on member states' domestic situations.

As an international norm, R2P has been generally accepted by most countries in the world (Alexandra, 2012, p. 55). This norm was endorsed through the 2005 UN World Summit and incorporated in UN Security Council Resolution No. 1674. Borrowing Sikkink and Finnemore's terminology, we can conclude that R2P is in the cascade phase, in which the majority of the world states have agreed on the basic propositions of the norm (Finnemore \& Sikkink, 1998). There has been debate concerning the justification of the R2P concept, as most state leaders see sovereignty as sacred. As such, proponents around the world have discarded the

1. The Secretary-General of ASEAN, assisted by the ASEAN Secretariat or any other designated ASEAN body, shall monitor the compliance with the findings, recommendations or decisions resulting from an ASEAN dispute settlement mechanism, and submit a report to the ASEAN Summit.

2. Any Member State affected by non-compliance with the findings, recommendations or decisions resulting from an ASEAN dispute settlement mechanism, may refer the matter to the ASEAN Summit for a decision.

Please refer to the ASEAN Charter, available online at https://asean.org/storage/images/archive/publications/ASEANCharter.pdf.

${ }^{12} \mathrm{R} 2 \mathrm{P}$ is stated in this resolution as a "primary responsibility to take all feasible steps to ensure the protection of affected civilians." It initial idea of the "responsibility to intervene" and adopted the down-toned term "responsibility to protect." Alexandra argues that, although leaders from different cultures might now recognise the importance of R2P, its implementation must be justified with the existence of "intolerable violence" (Alexandra, 2012, p. 52).

While the majority of world leaders have agreed with the enactment of UN Security Council Resolution no. 1674 (2006) on Protection of civilians in armed conflict, ${ }^{12}$ this has not been the case in ASEAN (Belammy \& Beeson, 2010). Until it was revealed by Secretary-General Surin Pitsuwan, the intention to incorporate R2P in ASEAN was not known by the international community.

\section{ASEAN Bureaucrats as R2P Proponents}

Former ASEAN Secretary-General Surin Pitsuwan has undoubtedly been the strongest proponent of R2P internalisation in ASEAN. His remarkable speech at the October 2008 ASEM Summit, which responded to ASEAN's involvement in Myanmar following Cyclone Nargis, is considered to have assertively advocated for R2P implementation in the region. Pitsuwan frankly told the public that what he had imposed in Myanmar was an action based on R2P considerations; he even mentioned that the principle of non-interference could be obstructive to humanitarian response. ${ }^{13}$ Furthermore, he argued that it is the responsibility of the international community to provide assistance and support to people in need.

encompasses the responsibility of international community to protect people from four mass atrocities: genocide, war crimes, ethnic cleansing and crimes against humanity. Please refer to the resolution, available online at https://www.un.org/ruleoflaw/blog/document/security-councilresolution-1674-2006-on-protection-of-civilians-in-armed-conflict/. ${ }^{13}$ Surin Pitsuwan's speech, as retrieved from the ASEAN Secretariat: "... Responsibility to Protect or human security doctrine or the principle of non-interference - all these were elements that can both be helpful and at the same time obstructive or restrictive to our humanitarian response. That is a challenge for diplomacy." 
His speech and intervention in Myanmar may be identified as an entry point for R2P in ASEAN regionalism.

In 2014, Surin Pitsuwan once again took a pivotal role in the development of a working framework in ASEAN when he led a high-level advisory panel on R2P in Southeast Asia. This panel strategically devised tools to internalise R2P by playing two-level games. Regionally, ASEAN should create new functions for its already established infrastructure, i.e. early warning and the capacity to investigate potential threats to humanity, including crimes against humanity, war crimes, ethnic cleansing, and genocide. Domestically, ASEAN member countries should be convinced to ratify all of the international conventions related to human rights and humanitarianism.

Changes to the R2P concept in 2009 helped Surin Pitsuwan introduce its implementation. As initially proposed in 2001, R2P drew the antagonism of state leaders who held an absolute stance on sovereignty. Regime survival is a major motive for governments, who seek to safeguard their administrations from foreign intervention. The criticism of the international community is often regarded as a delegitimising action. The new formulation of R2P emphasised each government's role in protecting its people. The international community also has the responsibility to provide support based on the consent of each respective government. If a government fails to protect its population, the international community-under the authorisation of the UN-should take measures to assure the protection of threatened people (Alexandra, 2012, p. 52).

Another thing that should be taken into consideration is that ASEAN bureaucrats found it easier to use toned-down terminologies. They considered terms such as "humanitarian aid" and

\footnotetext{
14 On October 2017, AHA Centre dispatch80 tons of aid to the displaced people in Rakhine State, Myanmar. Please refer to the AHA Centre official release, available online at
}

"humanitarian assistance" as more applicable to ASEAN than "R2P" or "humanitarian intervention". The word "intervention" was deemed harmful for state leaders, either because theirs were authoritarian regimes, or they needed to carefully address domestic pressures to defend their sovereignty. For example, the operating arms for incorporating R2P in the region are managed through ASEAN Political-Security Community (APSC), the ASEAN Intergovernmental Commission on Human Rights (AICHR), and the ASEAN Coordinating Centre for Humanitarian Assistance on Disaster Management (AHA Centre). In the case of AHA Centre, albeit focused on disasters, the mandate may be expanded to a human-induced disaster as demonstrated in 2017 humanitarian operation in Rakhine State. ${ }^{14}$ This proves that R2P installation is possible with toned-down terminology. Meanwhile, forcefully using the term R2P as the basis for ASEAN involvement in dealing with international assistance might be understood wrongfully. Even today, many people still misunderstand R2P as an unilateral intervention, use of military force, and a service to major countries' interest in gaining more power. ASEAN member countries, thus, have tended to be afraid of R2P being misused to justify unilateral intervention.

As such, ASEAN bureaucrats have been careful not to show their true intention for incorporation. In 2009, following Cyclone Nargis, ASEAN Director Secretary for Security and Politic Termsak Charlermpalanupap argued for the need to reiterate non-interference, consultation, and consensus, to maintain conformity. Saving face is still regarded as important in order to invite troubled countries into a regional engagement.

https://ahacentre.org/press-release/aha-centre-delivers-80-tons-ofrelief-materials-to-rakhine-state-myanmar/. 


\section{Academic Proponents of R2P in ASEAN}

Other than ASEAN bureaucrats, several international scholars such as Noel Morada, a Filipino Scholar at the University of Queensland, argues that R2P should be seen as complementary to the ASEAN Charter because it will strengthen democracy, rule of law, and good governance. Morada argues that many people have a mistaken impression of R2P. In Southeast Asia, R2P has been considered detrimental to the sovereignty of the state. Modara argues that this is not correct; R2P is important for sovereignty because its implementation will help governments gain more credibility (Myanmar Times, 2017).

In Thailand, Kraisoraphong (2012) argues that the enthusiasm in campaigning for R2P is originates from academic institutions. One of the most progressive institutions in introducing R2P in Thailand is the Institute for Peace and Conflict Studies at Chulalongkorn University (Kraisoraphong, 2012, p. 6). Another research institution undergoing a thorough examination of R2P is the International Affairs Committee to the Senate (Kraisoraphong, 2012, p. 6). Academic works have been published in Thai to provide general knowledge on R2P by Thai scholars like Chaiyanam (2009). Kraisoraphong finds that the book is designed for ordinary readers by giving highlights of R2P basic principles and debates on its implementation such as whether it is justified or not to launch a humanitarian intervention in cases like Myanmar Cyclone Nargis (Kraisoraphong, 2012, p. 6).

Hikmahanto Juwana, a professor of international law at Universitas Indonesia, has taken a firmer stance when responding to clashes between the Rohingya and Myanmar security forces on 25 August 2017, arguing that the Myanmar security forces were involved in ethnic cleansing (Juwana, 2017). According to Juwana, the Myanmar government lacked the capacity to control its security people in the field. Reports showed that security personnel had responded to social disturbances with violent assaults. Provoked by misleading news and prejudices, security forces committed atrocities against the Rohingya. Weak ASEAN responses to these atrocities were caused by the prolonged debate over whether the ASEAN Charter tolerates foreign intervention (Juwana, 2017).

In his attempt to explain the logic of R2P, Juwana argues for humanitarian intervention using the analogy of a family. If, within a family, a husband is violent towards his wife or children, according to Southeast Asian customs, it is the neighbours' responsibility to file a police report (Juwana, 2017). Moreover, he argued that the international community has agreed upon R2P since the signing of the 2005 UN document. He strongly recommends that ASEAN implement the norm, giving Myanmar an ultimatum to punish its security forces for their atrocities or face ASEAN intervention. Juwana proposes a warning of economic sanctions as the first step, which would likely result in similar actions from countries such as the United States, Japan, and the EU member states.

\section{State Leaders as Proponent of R2P in ASEAN}

At the international level, a strategic shift has been experienced by decision-makers in the United Nations. It is important to note that several scholars have covered the dynamics of R2P formulation. The initial R2P concept, as developed in 2001, emphasised the use of military deployment to intervene in other countries where humanitarian crimes are committed. This concept was proposed by the International Commission on Intervention and State Sovereignty (ICISS), which was established to help answer then-UN Secretary-General Kofi Annan's question about what the international community should do to respond to crimes against humanity in Rwanda and Srebrenica in 
Bosnia and Herzegovina. ICISS responded by formulating justifications and conditions for military intervention, not only including crimes against humanity but also natural disasters and environmental problems (Alexandra, 2012, p. 52). Among the twelve senior leaders involved was Fidel Valdez Ramos, who had served as President of the Philippines from 1992 to 1998. This shows that a Southeast Asian leader could also provide such firm support for the principle, even as it demonstrates gaps in Southeast Asian cultures' adherence to democratic principles.

In the 2005 document discussing the voting process in the UN, 75 of 93 participating countries supported R2P. This number shows the division within the international community, in which many countries-about $19.35 \%$ of the total population (ICRtoP, 2009) ${ }^{15}$-still opposed the use of the concept. The strongest proponent of R2P in its early stages were African countries, which were increasingly concerned with crimes against humanity in the continent (Alexandra, 2012, p. 52). Meanwhile, most ASEAN countries cast their support for R2P, but under the condition that its implementation should be under scrutiny to avoid the political influence of powerful countries. The actual mood of Southeast Asian countries was indeed less welcoming to R2P. Indonesia, considered one of the most advanced democracies in ASEAN, has shown some concern for human rights but experienced rejection on several occasions. For example, while designing the ASEAN Intergovernmental Human Rights Commission, Indonesia's proposal to provide the commission with the ability to investigate alleged human rights violations through fact-finding activities was vetoed by other ASEAN member states. In the case of R2P, ASEAN member states preferred voting for support, as they understood the UN

\footnotetext{
${ }^{15}$ Please refer to the General Assembly Debate on the Responsibility to Protect and Informal Interactive Dialogue document. Provided by the International Coalition for the Responsibility to Protect (ICRtoP) on July 2009 available online at
}

outcome document for R2P would have no immediate legal power. This makes sense since ASEAN countries were already familiar with navigating non-legally binding agreements at the regional level.

The moment when then-UN SecretaryGeneral Ban Ki-Moon issued a report on R2P implementation marks a crucial moment in the organisation's monitoring of countries' compliance with the newly installed norm. This is because, as suggested by Sikkink and Finnemore, when a new norm finally passes its tipping point, there will be subtle rejections by dissatisfied countries (Finnemore \& Sikkink, 1998, p. 898).

In a discussion with Indonesian Foreign Minister Retno Marsudi on 16 December 2017, organised by the Department of International Relations, Universitas Gadjah Mada, Marsudi stated that the Indonesian Ministry of Foreign Affairs has never formally used such a concept. However, the position of President Joko Widodo's administration was to provide aid to the Rohingya and protect their rights in Rakhine State (Kapoor, 2017). This is in accordance with the proposition of R2P, which promotes protecting people regardless of national borders in cases of crime against humanity, war crimes, ethnic cleansing, and genocide.

In Malaysia, the leader who has adhered closely to the need to implement R2P is the current de facto leader of Pakatan Harapan (a coalition of parties that won the 2018 Malaysian General Election), Anwar Ibrahim. In 1997, he proposed a firmer stance on democratisation in the region, and through his concept of "constructive engagement," he urged ASEAN to develop a mechanism for member states to intervene in promoting human security through economic, human rights, and education programmes (The Asia-Pacific Center for

http://www.responsibilitytoprotect.org/index.php/component/con tent/article/35-r2pcs-topics/2493-generalassembly-debate-on-theresponsibility-to-protect-and-informal-interactivedialogue-. 
Responsibility to Protect, 2009, p. 33). When Ibrahim was detained by Mahathir Mohamad in 1998, Indonesia and the Philippines made an attempt to pressure the Malaysian government as a gesture that may conflict with the principle of non-interference in ASEAN. Presidents B.J. Habibie of Indonesia and Joseph Estrada of the Philippines criticised Mahathir for jailing Anwar Ibrahim. Malaysia retaliated by stressing ASEAN member states should not concern themselves with Malaysian domestic politics, threatened to block the employment of Indonesian and Filipino workers, and indicated an intention to support Malay or Bangsa Moro insurgencies in the southern Philippines (Bellamy \& Drummon, 2011, p. 187). Importantly, this last threat was actually in violation of the principle of non-interference.

ASEAN has a set of principles, termed the "ASEAN Way", which include dealing with disputes through consensus and consultation, respect for the sovereignty of member states, harmony, prioritising peace, renunciation of violence, and ensuring stability. This paper discusses how this principle is being institutionalised in the ASEAN Secretariat and the AHA Centre. In dealing with natural disasters, ASEAN must also indirectly deal with human security problems. ${ }^{16}$ In a Southeast Asian context, problems are complicated when affected areas are conflict zones. This is a big dilemma for those who are working with this type of situation. The role of ASEAN in dealing with Cyclone Nargis in 2008 is one example. Since the establishment of the AHA Centre in November 2011, in the first year

\footnotetext{
${ }^{16}$ Human security has been understood as a means to reducing human cost in violent conflicts. -Not only in dealing with militarythreats, human security is now moving into a wider arrange of human needs. When a disaster struck an area with internal conflict, it will add complexity on the response and recovery process Nishikawa highlighted that the complex roots for internal violent conflicts in Southeast Asia has generated existing threats to human security in the region through the case of Southern Thailand. Nishikawa argued that not only violent threats but, human security should also encompass non-traditional issues such as hunger, disease, and natural disaster.

${ }^{17}$ Responseteam were deployed on a flood mission to Thailand on 15-24 October 2011. The second mission was deployed to respond
}

of AHA Centre operation, two disaster response operations have been undertaken. ${ }^{17}$

The interview with the AHA Centre representative garnered some interesting insights. When Cyclone Mahasen was approaching Myanmar in May 2013, the international community had enormous concern for the tens of thousands of Rakhine refugees who were vulnerable. Similarly, when responding to Typhoon Bopha after it struck Mindanao in the Philippines in December 2012, the international community was concerned about whether or not Muslims would receive equal protection. Flooding in Thailand, from late 2011 through the beginning of 2012, was also marked by internal political tensions when newly elected Prime Minister Yingluck Shinawatra faced a significant challenge from her political opponents, who criticised her administration's ability to deal with the flooding. As such, ASEAN operations were conducted carefully to avoid any uncomfortable situations that could cause the failure of humanitarian operations.

Director of ASEAN Socio-Cultural Cooperation at Ministry of Foreign Affairs of the Republic of Indonesia, Riaz Januar Putra Saehu, stated that Indonesia considers ASEAN cooperation on disaster management as an important instrument to strengthen member states solidarity. ${ }^{18}$ Hence, the Indonesian administration fully supported the establishment of AHA Centre. Indonesia provides the AHA Centre headquarter and technology infrastructures in Jakarta. The latest progress in AHA Centre shows a limited expansion of AHA

to a 6.8 magnitude earthquake occurred nearby Shwe Bo, Myanmar on 11 November 2012. Meanwhile on the latest update in 2018, AHA Center has deployed response teams six times; 1). preparedness mission in Rakhine State in January 2018, 2). Yangon landfill fire in April 2018, 3). TS-11 Floods in Myanmar and Laos in July-August 2018, 4). Lombok earthquakes in Indonesia in July 2018, 5). Typhoon Mangkhut in the Philippines in September 2018, and 6). PaluDonggala earthquakes in Indonesia in September 2018. Please refer to the AHA Centre Annual Report 2018: Breaking New Ground.

18 The discussion with Riaz Saehu was conducted on 10 July 2019 in the Faculty of Social and Political Science, Universitas Gadjah Mada, Yogyakarta, Indonesia. 
Centre's operation. Recently, AHA Centre is deployed to respond to human-induced disasters such as humanitarian issue in Rohingya. Saehu iannounced that endorsed by Indonesian President Joko Widodo and Indonesian Minister of Foreign Affairs Retno Marsudi. Saehu affirmed that ASEAN Secretary-General Lim Jock Hoi supported Joko Widodo and Retno Marsudi's idea to expand AHA Centre's role in addressing the humanitarian issue in Myanmar. In response to the pressure, Myanmar's government decided to welcome AHA Centre's team for the Rohingya's case. Thus, AHA Centre could deploy an assessment team and aid to Rohingya people in Rakhine State. Saehu added that Retno Marsudi also directed the Indonesian Ministry of Foreign Affairs to send staff to join AHA Centre operations.

As gathered from interviews, focal points or competent bodies in affected countries have generally expressed satisfaction with the operations performed by the AHA Centre, which utilises the modalities of trust and confidencebuilding. Person-to-person contact is another relevant factor in the success of operations. According to the AHA Centre, operations must also give the government of the affected country space to play its centrality. As such, these findings strengthen the initial hypothesis that the ASEAN Way is still a paramount principle, however, it incrementally moves toward progress as showcased to the recent Rohingya's case.

\section{Conclusion}

Through an assessment of actors' positions and stances, we can draw some conclusions. First, although it was approved at the 2005 UN World Summit by 73 countries, R2P has not reached the tipping point in ASEAN. Albeit Southeast Asian countries signed to approve the outcome document, most did so because it does not have effective compliance mechanisms. In the meantime, they blocked the advancement of the norm within the region. This reluctant, or rather two-faced stance, was taken to ensure their reputation internationally and ensure their regime survival domestically. However, this multifaceted diplomatic position reflects the plural political systems within the countries of Southeast Asia. Fragmented opinions and dissenting positions from scholars, leaders, and bureaucrats-in Indonesia, for example-show that a certain degree of political openness has enabled different voices to battle for primacy.

Second, this study has shown that Sikkink and Finnemore's assessment of the dynamics of international norms must be enriched through a discussion of what happens when a norm has reached its tipping point. In this research, we found that tipping points in international forums may not necessarily be well-reflected at the regional level. There will be subtle rejections and half-willed intentions from countries, hoping to maintain the status quo or at least prolong the internalisation process, as the implementation of R2P in ASEAN will have an effect on domestic politics. In this situation, both ASEAN bureaucrats and leaders will tone-down or encode their support for R2P.

Third, the tipping point measurement needs to be revisited. Apparently, more than onethird of total member states must commit to the new norm in order to bring R2P to its tipping point in ASEAN (Finnemore \& Sikkink, 1998, p. 898). However, political change in Thailand and the Philippines might have impacted the calculated number. In the inclusion of the norm in ASEAN regionalism, such as regional disaster management or the Rohingya case, only Indonesia has been on board.

\section{Acknowledgement}

The author extends his gratitude to Prof. Shimada Yuzuru, as academic supervisor and promoter, for his guidance and comments that significantly improve this work, Prof. Yamagata Hideo for his 
constructive suggestions to help focus the research, and Prof. Nishikawa Yukiko for providing perspective and relevant literature on the Responsibility to Protect in Southeast Asia.

\section{Author Biography}

Muhammad Rum is a Ph.D. Candidate at the Graduate School of International Development, Nagoya University. $\mathrm{He}$ is also an assistant professor at the Department of International Relations, Universitas Gadjah Mada.

\section{References}

Alexandra, L (2012). Indonesia and the Responsibility to Protect. The Pacific Review, 25(1), 51-74.DOI: 10.1080/09512748.2011.632964

Belammy, A., \& Beeson, M. (2010). The Responsibility to Protect in Southeast Asia: Can ASEAN Reconcile Humanitarianism and Sovereignty? Asian Security, Vol. 16, No. 3. DOI: $10.1080 / 14799855.2010 .507414$

Bellamy, A. \& Drummon, C. (2011). The Responsibility to Protect in Southeast Asia: Between Non-Intervention and Sovereignty as Responsibility. The Pacific Review, 24( 2), 179-200. DOI: 10.1080/09512748.2011.560958

Caballero-Anthony, M. (2008). The ASEAN Charter: An Opportunity Missed or One that Cannot be Missed? Southeast Asian Affairs, 71-85.

Capie, D. (2012). The responsibility to Protect Norm in Southeast Asia: Framing Resistance and the Localization Myth. The Pacific Review, 25(1). DOI: 10.1080/09512748.2011.632967

Evans, G. (2008). The Responsibility to Protect: Ending Mass Atrocity Crimes Once and for All. Washington DC: Brookings Institution Press.

Ferris, E., \& Petz, D. (2013). In the Neighborhood: the Growing Role of Regional Organizations in Disaster Risk Management. Washington:
The Brookings Institution, London School of Economic Project on Internal Displacement.

Juwana, H. (2017, September 15). Kewajiban ASEAN Melindungi Myanmar. Retrieved from Fakultas Hukum Universitas Indonesia: http://law.ui.ac.id/v3/kewajiban-aseanmelindungi-myanmar/

Kapoor, A. (2017, September 4). Indonesian Minister to Meet Suu Kyi amid Protests over Rohingya. Retrieved from reuters: https://www.reuters.com/article/usmyanmar-rohingya-indonesia/indonesianminister-to-meet-suu-kyi-amid-protestsover-rohingya-idUSKCN1BFOPY

Kraft, H. (2012). R2P by Increments: the AICHR and Localizing the Responsibility to Protect in Southeast Asia. The Pacific Review, 25(1). DOI: 10.1080/09512748.2011.632963

Kraisoraphong, K. (2012). Thailand and the Responsibility to Protect. The Pacific Review, 25(1), 1-25. DOI: 10.1080/09512748.2011.632960

Nesadurai, H. (2009). ASEAN and Regional Governance after the Cold War: From Regional Order to Regional Community? The Pacific Review, 1(22), 91-118.DOI: 10.1080/09512740802651169

Nishikawa, Y. (2018). The reality of protecting the Rohingya: An inherent limitation of the responsibility to protect. Asian Security. DOI: 10.1080/14799855.2018.1547709

Pattison, J. (2011). The Ethics of Humanitarian Intervention in Libya. Ethics \& International Affairs, 25(3), 271-277.DOI: 10.1017/S0892679411000256

Rum, M. (2016). The Case of Regional Disaster Management Cooperation in ASEAN: A Constructivist Approach to Understanding How International Norms Travel. Southeast Asian Studies, 5(3), 491-514. DOI: 10.20495/seas.5.3_491 